Research Article

\title{
Ameliorative Effect of Infused Watercress on Rat Galactopoiesis Following Maternal Separation
}

Rahadian Yudo Hartantyo, Ucik Erlitaningsih, Jeremia Gerald, Indah Permata Sari, Laksmindra Fitria, Mulyati

Department of Tropical Biology, Faculty of Biology, Universitas Gadjah Mada, Yogyakarta 55281, Indonesia

Article history:

Submission August 2018

Revised August 2018

Accepted September 2018

*Corresponding author:

E-mail: rahadian.yudo@ugm.ac.id

\begin{abstract}
Galactopoiesis is the maintenance of milk production. The process that regulated primarily by prolactin hormone. The research was conducted to evaluate galactopoiesis activity by measuring prolactin level and milk production continuity of lactating rats after oral administration of infused watercress. Twenty lactating rats were randomly divided into five groups (two control groups and three variations of infused watercress dose groups). Serum prolactin was measured using enzyme-linked immunosorbent assay. Milk yield was measured using indirect milk measurement method by Sampson and Jansen. Milk protein level was measured using Kjedahl method. The treatment of infused watercress $(10 \mathrm{~g} / \mathrm{kg}$ body weight), started from postnatal day 3 until 12, indicated ameliorative effect on rat galactopoiesis by increasing milk yield and prolactin levels, but not milk total protein.
\end{abstract}

Keywords: Galactopoiesis, prolactin, milk protein, watercress

\section{Introduction}

World Health Organization (WHO) recommends exclusive breastfeeding during the first six months infant early life [1]. Milk is the most appropriate natural nutrient for optimal infant growth. Like in human, rat milk contains protein, lactose, and lipid [2].

Milk is produced by mammary alveolar epithelial cells (AEC). AEC take up blood nutrients from capillary network as milk raw materials [3]. Molecule transport into AEC cytoplasm involve several types of transporters and channels, including Aquaporin 3 (AQP3) for water and glycerol transport, GLUT-1 for glucose transport, SLC27A for long chain fatty acid transport, neutral amino acid transporter 1 (ASCT1) and cationic amino acid transporter (CAT1) for amino acid transport $[4,5,6,7]$.

Caseins and whey acidic protein synthesis are stimulated by hormonal regulation via Signal Transducer and Activator of Transcription 5 (STAT5) activation during gestation [8]. Milk lactose is synthetized from glucose and UDP-galac- tose at the Golgi apparatus [9]. Triglyceride is synthetized from glucose, glyceride, and fatty acids at the surface of rough endoplasmic reticulum. Trygliceride forms small cytoplasmic lipid droplets (CLD). Furthermore, milk components transferred to the apical membrane of mammary alveolar epithelial cells and secreted into alveolar lumen via specific pathways [10].

Caseins and lactose are secreted into lumen by exocytosis with regulation of SNARE (soluble Nethylmaleimide-sensitive factor attachment protein receptor) proteins i.e. SNAP-23, syntaxin-6, syntaxin-7, syntaxin-12, VAMP-4, and VAMP-8 $[11,12]$. Small CLDs are covered with coat proteins and polar lipids then fused each other to form larger CLD [13]. Adipophilin is suggested as adaptor linking CLD to SNARE proteins regarding exocytosis [14].

Milk production primarily affected by the mammary gland development and the demand of the offspring for milk. Mammary gland development is divided into two step, lactogenesis 1 that begins in mid pregnancy and lactogenesis 2 at 
around the parturition indicated with colostrum and milk secretion. Endocrine regulation is the main regulatory mechanism in mammary gland development. There are three hormone categories involved: the reproductive hormones (i.e. estrogens, progesterone, prolactin, oxytocin, and placental lactogen), metabolic hormones (i.e. growth hormone, thyroid hormone, insulin, and corticosteroids), and mammary hormones (i.e. prolactin, parathyroid hormone-related protein, growth hormone, and leptin) [15].

Watercress (Nasturtium officinale) is one of Indonesian vegetables that used as natural galactogogue in Central Java, Indonesia. There are limited scientific information about the effect of infused watercress on milk production continuity (galactopoiesis). Previous study by Salamah et al. showed that watercress contains several bioactive compounds including alkaloids, steroids, hydroquinone phenols, carbohydrates and amino acids [16]. The present study was performed to extend those local wisdom to scientific measurement of the watercress effect on prolactin level, milk yield, milk protein at preclinical level.

\section{Material and Methods Plant sample preparation}

Aerial parts of watercress (Nasturtium officinale) was obtained in Sleman district (Yogyakarta, Indonesia) and identified in Faculty of Biology, Universitas Gadjah Mada. The plant samples were extracted using infusion method. Samples were cut into smaller size, weighed, and added with water. The mixture was boiled for $5-10$ minutes at $\pm 90^{\circ} \mathrm{C}$. Then, the liquid part (infusion) were separated from the pulp and stored at $4^{\circ} \mathrm{C}$ for future use.

\section{Animals, housing, and ethical statement}

Wistar rats (Rattus norvegicus Berkenhout, 1769) from Universitas Gadjah Mada Integrated Research and Testing Laboratory were mated at the animal facility in Faculty of Biology, Universitas Gadjah Mada. The pregnant rats (dams) were single-housed in standard cages $(40 \mathrm{~cm} \times 30 \mathrm{~cm} \times$ $25 \mathrm{~cm}$ ) with standard pellet food and tap water ad libitum. The individual cages contained woodchip bedding and were maintained in constant temperature $\left(26-27^{\circ} \mathrm{C}\right)$ and humidity $(76-88 \%)$ on a 12-hour light/dark cycle. The animal experimental protocol was approved by Universitas
Gadjah Mada Committee of Ethical Clearance for Preclinical Research (Ref. No. 00008/04/LPPT/ V/2016).

\section{Animal treatment}

After parturition, the dams were divided into five groups, each containing four dams: the first group was given $1 \mathrm{~mL}$ distilled water (placebo) as the normal control group (CNT). The second group was given a dose of Domperidone (PT. Indofarma, Bekasi, Indonesia) $3 \mathrm{mg} / \mathrm{kg}$ body weight as the positive control group (DMP). Other groups were given a daily single dose of infused plant 5, 10, and $15 \mathrm{~g} / \mathrm{kg}$ body weight (WT5, WT10, and WT15 respectively). All substances mentioned were administered by oral gavaging for ten consecutive days, started at postnatal day 3 until 12 (PND 3 until PND 12). The administration was given following 4 hours maternal separation.

\section{Maternal separation}

Started from PND 3 until PND 12, the dams were separated from the pups into other cages for four hours then put back into their origin cages. The cages contained wood-chip bedding and were maintained in constant temperature $\left(26-27^{\circ} \mathrm{C}\right)$ and humidity (76-88\%) on a 12-hour light/dark cycle.

\section{Blood and milk sampling}

Blood and milk sampling were collected from dams at postnatal day 13 (PND 13). The dams were anesthetized with Ketamine HCl Ketalar ${ }^{\circledR}$ (Pfizer, Jakarta, Indonesia) $50 \mathrm{mg} / \mathrm{kg}$ body weight via intramuscular. The blood samples were collected from supraorbital sinus, left coagulated for 10 minutes, and centrifuged at $10,000 \mathrm{rpm}$ for 10 minutes. The supernatant (serum) was separated and kept under $-15^{\circ} \mathrm{C}$ for hormone analysis.

Milk sampling was conducted under anesthesia condition. The dams were administered with $0.02 \mathrm{~mL}$ synthetic oxytocin PitoginTM 10 IU (PT Ethica, Jakarta, Indonesia) intraperitoneal and incubated for 15 minutes. Mammary glands of dams were gently massaged. Ejected milk was collected using micropipette and stored using microtube under $-15^{\circ} \mathrm{C}$ for protein analysis.

\section{Milk yield}

At postnatal days 5, 7, 9, 11, the pups were weighed after 4 hours of maternal separation and 


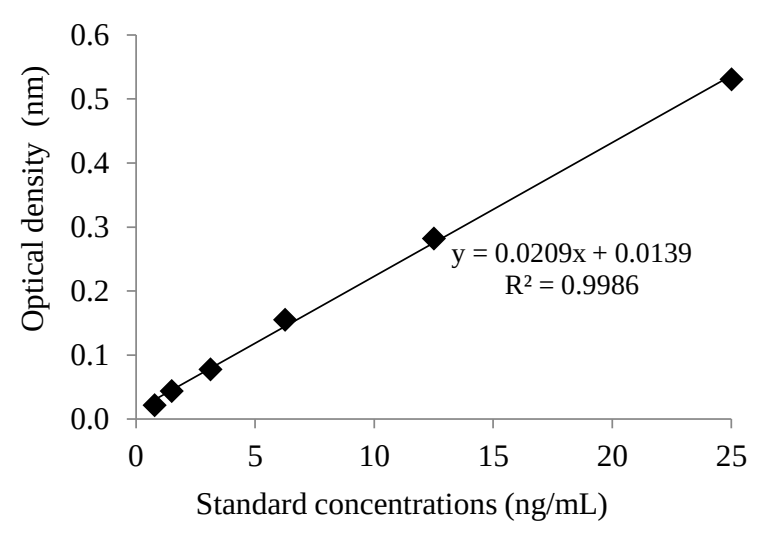

Figure 1. Standard curve for prolactin measurement obtained using Rat PRL ELISA kit catalog No. E-EL-R0052 for standard prolactin concentrations: $0.781 \mathrm{ng} / \mathrm{mL} ; 1.563 \mathrm{ng} / \mathrm{mL}$; $3.125 \mathrm{ng} / \mathrm{mL} ; 6.25 \mathrm{ng} / \mathrm{mL} ; 12.5 \mathrm{ng} / \mathrm{mL}$; and $25 \mathrm{ng} / \mathrm{mL}$

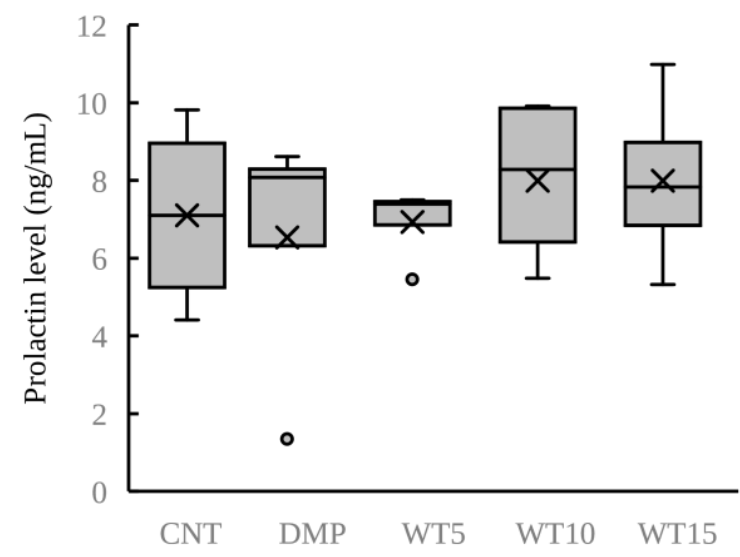

Figure 2. Serum prolactin level of the dams sampled after ten days treatment period (postnatal day /PND 13). CNT: control group; DMP: domperidone group; WT5, WT10, WT15: infused water treatment 5, 10, $15 \mathrm{~g} / \mathrm{kg}$ body weight, respectively. Data are presented as mean (x) and median with upper and lower quartiles, min and max values and outliers (o).

followed by 2 hours of unification. Sampson and Jansen (1984) formula was used to calculate the milk yield [17].

$$
Y=(0.0332+0.667 W+0.877 G) \times L
$$

Note:

Y : Milk yield (g/dam/day)

$\mathrm{W}$ : Initial weight (g)

$\mathrm{G}$ : Weight gain (g)

L : Number of litters

\section{Hormone analysis}

Frozen serum samples were thawed before performing assay. Serum prolactin levels were measured using enzyme-linked immunosorbent assay according to Rat PRL ELISA kit katalog No. E-EL-R0052 (Elabscence Biotechnology, Texas, USA). All samples were analyzed in duplicate. Standard curve of prolactin measurement using Rat PRL ELISA kit was presented in Figure 1. The optical density (OD value) of each standard sample were determined using a micro-plate reader set to $450 \mathrm{~nm}$ with duplication.

\section{Statistical analysis}

Prolactin level, Milk production, milk protein, and body weights were analyzed with the SPSS 22.0 (IBM corporation, USA) for one-way ANOVA followed with Duncan test. Tests were considered significant at $\mathrm{p}<0.05$.

\section{Results and Discussion \\ Prolactin (PRL) level}

The result of PRL measurement in postnatal day 13 is shown in Figure 2. Individual PRL levels of the postpartum dams were ranged at 4.41 to $10.99 \mathrm{ng} / \mathrm{mL}$. The highest median was in WT10 group $(8.29 \mathrm{ng} / \mathrm{mL})$ comparing with CNT (7.10 $\mathrm{ng} / \mathrm{mL}$ ) and other groups. Mean PRL level in DMP dams were lowest among other groups. Circulating PRL levels in dams that treated with infused watercress were higher than that level in CNT, but not in WT5 dams. Mean PRL levels were same $(7.99+1.12 \mathrm{ng} / \mathrm{mL})$ for both groups (WT10 and WT15) compared with CNT $(7.10+1.28 \mathrm{ng} / \mathrm{mL})$.

There was small difference in the PRL levels between control and treatment groups, but the differences were statistically non-significant $(\mathrm{p}<$ 0.05 ). Whereas in endocrine regulation, small change in hormone levels may yield significant impact effect on physiology.

PRL level regulation involves the central nervous system. The regulation is affected by several factors that suppress or stimulate the secretion of dopamine, as prolactin inhibiting hormone (PIH), by a neuronal group called Neuroendocrine Dopamine Neurons or NEDA [18]. High dopamine level inhibits prolactin synthesis by lactotroph cells.

Anterior pituitary has dopamine D2 receptors that play role in inhibiting PRL release. Domperidone is a dopamine D2 receptor antagonist [19]. 


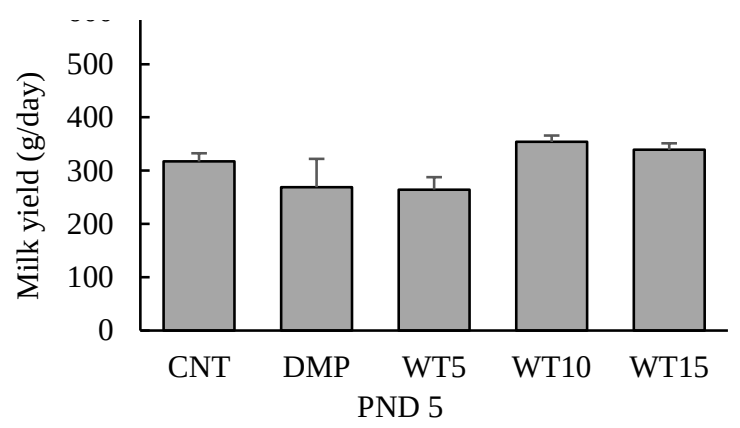

(a)

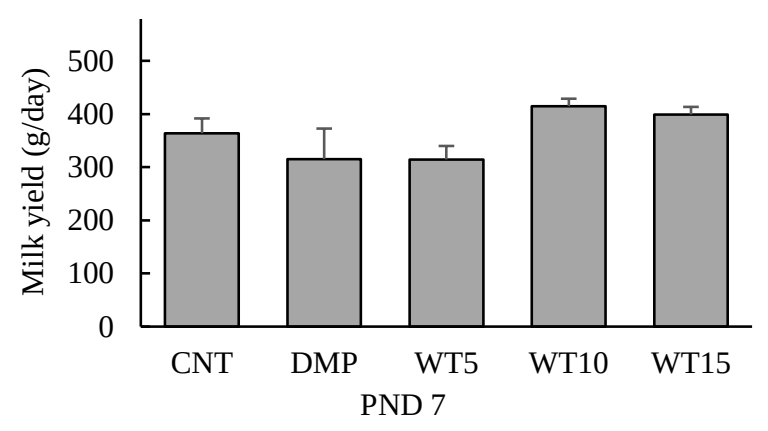

(b)

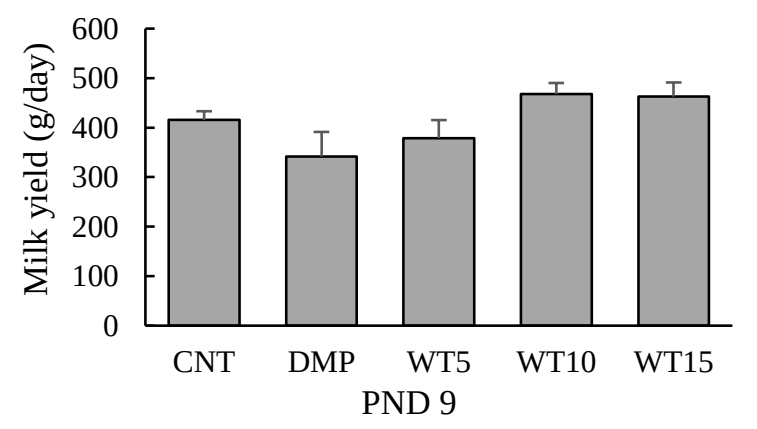

(c)

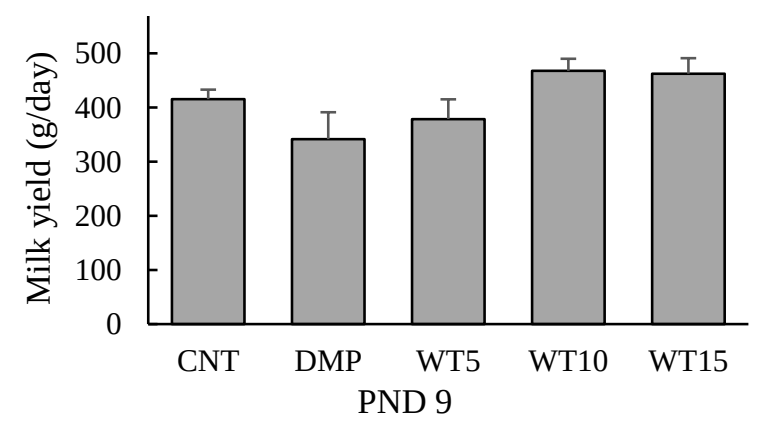

(d)

Figure 3. Milk production of dams sampled at postnatal day / PND 5 (a); PND 7 (b); PND 9 (c); and PND 11 (d). CNT: control group; DMP: domperidone group; WT5, WT10, WT15: infused watercress treatment at dose 5,10 , $15 \mathrm{~g} / \mathrm{kg}$ body weight, respectively. Data are presented as mean with S.E.M. $\mathrm{n}=4$ for all groups
By blocking dopamine D2 receptors in the anterior pituitary, domperidone stimulates the release of prolactin by lactotroph cells in anterior pituitary.

\section{Milk yield}

Figure 3 shows the milk yield per day for the 20 dams at postnatal day 5, 7, 9, and 11. Individual milk yield of the postpartum dams were ranged at $128.81 \mathrm{~g} /$ day (DMP dam at PND 5) to 613.43 g/day (WT10 dam at PND 11). Mean milk yield in WT10 group was highest among other groups at all sampling periods. Daily milk outputs in dams that treated with infused watercress were higher than those output in control dams, but not in WT5 dams. The watercress group (WT10) achieved a mean of $59.17 \%$ increase in milk volume (at postnatal day 11 per postnatal day 5) compared with those increase in control group (55.87\%).

Initial comparisons indicated that those in the watercress group (WT10 and WT15) produced more milk than those in the control group. Water soluble bioactive in watercress are suspected as the compounds which triggers milk production, either directly or indirectly.

The rate of milk secretion is regulated primarily by positive feedback mechanism. The mechanism involve suckling by offspring, oxytocin release, and myoepithelial contractions. The amount of mammary tissue and the ability to supply raw materials to this tissue are limiting factor to milk production in dairy species and rodents. Meanwhile, the demands of offspring determine the rate of milk production in human and animals with small number of offspring [15].

\section{Total milk protein}

Total protein content in dams milk at postnatal day 13 is shown in Figure 4. Total milk protein levels of the postpartum dams were ranged from 0.6 to $36.0 \mathrm{~g} / \mathrm{dL}$. Mean protein level in DMP dams $(24.0+6.0 \mathrm{~g} / \mathrm{dL})$ were highest among other groups. Mean protein level in dams that treated with infused watercress were higher than that those level in CNT. There was small difference in the total milk protein levels between control and treatment groups, but the differences were statistically non-significant $(\mathrm{p}<0.05)$.

Comparing serum prolactin measurement and milk total protein results, escalation of serum prolactin in the treatment groups (WT5, WT10, and WT15) without an increase in milk protein content 


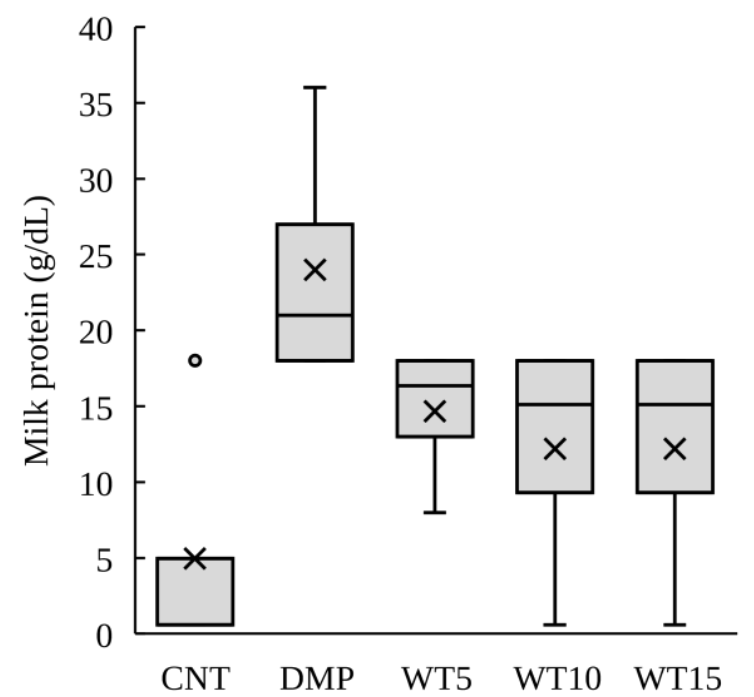

Figure 4. Total protein of rat milk sampled at postnatal day 13. CNT: control group; DMP: domperidone group; WT5, WT10, WT15: infused watercress treatment at dose $5,10,15 \mathrm{~g} / \mathrm{kg}$ body weight, respectively. Data are presented as mean $(\mathrm{x})$ and median with upper and lower quartiles, min and max values and outliers (o). $n=4$ for all groups

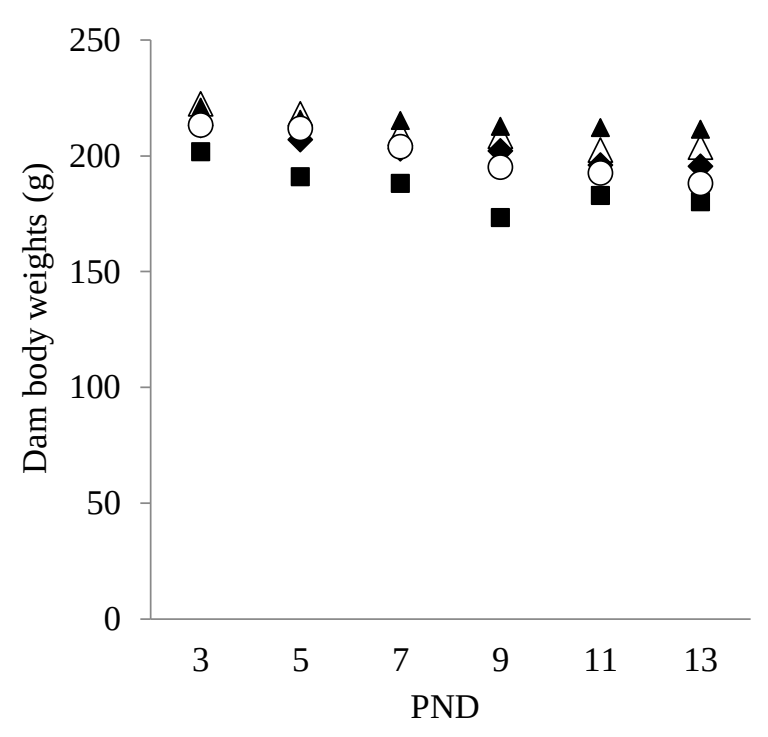

$\triangle \mathrm{CNT}$-DMP $\triangle \mathrm{WT5} \bullet \mathrm{WT} 10 \quad \mathrm{OWT} 15$

Figure 5. Dam body weights during treatment period. Mean dam body weights decreased over ten days observation for control group (CNT), domperidone group (DMP), and treatment groups i.e. infused watercress $5 \mathrm{~g} / \mathrm{kg}$ body weight (WT5), $10 \mathrm{~g} / \mathrm{kg}$ body weight (WT10), and $15 \mathrm{~g} / \mathrm{kg}$ body weight (WT15). PND, postnatal day. suggests that mediators or mechanisms other than prolactin should be involved in the milk protein synthesis. Despite the prolactin serum is permissive for lactation, but according to Cox et al. that there is a local role of autocrine control in milk synthesis [20].

\section{Rats body weight}

Figure 5 shows decreased rat body weights at PND 3 until PND 13. The sharpest decrease was WT15 dams (11.84\%) compared with CNT (8.38\%). Lactation during postpartum period increases the energy expenditure for milk production in the mammary glands thereby causing weight loss [21]. Weight loss after birth is influenced by several factors including parity, first gestational age, breastfeeding, and daily physical activity. Human breastfeeding expense about 500 $\mathrm{kcal} /$ day [22].

\section{Conclusion}

Based on the results, it can be concluded that the treatment of infused watercress $(10 \mathrm{~g} / \mathrm{kg}$ body weight), started from postnatal day 3 until 12, indicated ameliorative effect on rat galactopoiesis by increasing milk yield and prolactin levels, but not milk total protein.

\section{Acknowledgment}

The research on ameliorative effect of infused watercress on rat galactopoiesis was supported by BPPTNBH Universitas Gadjah Mada grant 1591/UN1-P.III/LT/DIT-LIT/2016 awarded to RYH.

\section{References}

1. WHO (2011) Infant and young child feeding. World Health 155 (May): A3929. http://www.who.int/news-room/fact-sheets/detail/infant-and-young-child-feeding. Accessed date: August 2018. doi: 10.1111/j.1740-8709.2009.00234.x.

2. Grigor MR, Allan J, Carne A et al. (1986) Milk composition of rats feeding restricted litters. Biochemical Journal 233 (3): 917 - 919. doi: 10.1042/bj2330917.

3. Andres AC, Djonov V (2010) The Mammary gland vasculature revisited. Journal of Mammary Gland Biology and Neoplasia 15 (3): 319 - 328. doi: 10.1007/s10911-010-9186-9. 3

4. Laspiur JP, Burton JL, Weber PSD et al. (2004) Short communication: Amino acid transporters in porcine mammary gland during lactation. Journal of Dairy Science 87 (10): 3235-3237. doi: 10.3168/jds.S0022-0302(04)73459-1. 
5. Macheda ML, Williams ED, Best JD et al. (2003) Expression and localisation of GLUT1 and GLUT12 glucose transporters in the pregnant and lactating rat mammary gland. Cell and Tissue Research 311 (1): 91 - 97. doi: 10.1007/s00441-002-0661-5.

6. Matsuzaki T, Machida N, Tajika Y et al. (2005) Expression and immunolocalization of water-channel aquaporins in the rat and mouse mammary gland. Histochemistry and Cell Biology 123 (4 - 5): 501 - 512. doi: 10.1007/s00418-005-0753-X.

7. McManaman JL (2014) Lipid transport in the lactating mammary gland. Journal of Mammary Gland Biology and Neoplasia 19 (1): 35 - 42. doi: 10.1007/s10911-014-9318-8.

8. Gallego MI, Binart N, Robinson GW et al. (2001) Prolactin, growth hormone, and epidermal growth factor activate Stat5 in different compartments of mammary tissue and exert different and overlapping developmental effects. Developmental Biology 229 (1): 163-175. doi: 10.1006/dbio.2000.9961.

9. Lin Y, Sun X, Hou X et al. (2016) Effects of glucose on lactose synthesis in mammary epithelial cells from dairy cow. BMC Veterinary Research 12: 81 - 91. doi: 10.1186/s12917-0160704-x.

10. Kobayashi K, Oyama S, Uejyo T et al. (2013) Underlying mechanisms involved in the decrease of milk secretion during Escherichia coli endotoxin induced mastitis in lactating mice. Veterinary Research 44 (1): 1 - 12. doi: 10.1186/1297-9716-44-119.

11. Chat S, Layani S, Mahaut C et al. (2011) Characterisation of the potential SNARE proteins relevant to milk product release by mouse mammary epithelial cells. European Journal of Cell Biology 90 (5): 401 - 413. doi: 10.1016/j.ejcb.2011.01.002.

12. Truchet S, Chat S, Ollivier-Bousquet M (2014) Milk secretion: The role of SNARE proteins. Journal of Mammary Gland Biology and Neoplasia 19 (1): 119 - 130. doi: 10.1007/s10911-0139311-7.

13. Heid HW, Keenan TW (2005) Intracellular origin and secretion of milk fat globules. European Journal of Cell Biology 84 (23): 245 - 258. doi: 10.1016/j.ejcb.2004.12.002.
14. Hatsu IE, McDougald DM, Anderson AK (2008) Effect of infant feeding on maternal body composition. International Breastfeeding Journal 3: 18 - 25. doi: 10.1186/1746-4358-3-18.

15. McManaman JL, Russell TD, Schaack J et al. (2007) Molecular determinants of milk lipid secretion. Journal of Mammary Gland Biology and Neoplasia 12 (4): 259 - 268. doi: 10.1007/s10911-007-9053-5.

16. Neville M, McFadden T, Forsyth I (2002) Hormonal regulation of mammary differentiation and milk secretion. Journal of Mammary Gland Biology and Neoplasia 7: 49 - 66.

17. Salamah E, Purwaningsih S, Permatasari E (2011) Aktivitas Antioksidan dan Komponen Bioaktif pada Selada Air ( Nasturtium officinale L . R . Br ). Jurnal Pengolahan Hasil Perikanan Indonesia 14 (2): 85 - 91.

18. Mello PRB, Okay TS, Botelho C (2007) The effects of exposing rats to cigarette smoke on milk production and growth of offspring. Jornal de Pediatria 83 (3): 267 - 273. doi: 10.2223/JPED.1620.

19. Grattan D, Tissier P (2015) Hypothalamic control of prolactin secretion, and the multiple reproductive functions of prolactin. In: Plant T, Zeleznik A (Eds.) Knobil and Neill's physiology of reproduction: Two-Volume Set 1 . San Diego, Academic Press. pp 469 - 526.

20. Barone JA (1999) Domperidone: A peripherally acting dopamine 2 -receptor antagonist. Annals of Pharmacotherapy 33 (4): 429 - 440. doi: 10.1345/aph.18003.

21. Cox DB, Owens RA, Hartmann PE (1996) Blood and milk prolactin and the rate of milk synthesis in women. Experimental Physiology 81 (6): 1007 - 1020. doi: 10.1113/expphysiol.1996.sp003985.

22. Padmawati R, Dasuki D, Sudargo T (2016) Breastfeeding to reduce postpartum weight retention. International Journal of Community Medicine and Public Health 3 (12): 3504 - 3510. doi: 10.18203/2394-6040.ijcmph20164282. 